\begin{tabular}{ll}
\hline Bentham OPen & The Open Dentistry Journal \\
\hline CrossMark & Content list available at: www.benthamopen.com/TODENTJ/ \\
\hline DOI: $10.2174 / 1874210601812010510,2018,12,510-519$ & $\begin{array}{l}\text { The } \\
\text { Open Dentisty } \\
\text { lournal }\end{array}$ \\
\hline
\end{tabular}

RESEARCH ARTICLE

\title{
The Association between Ponticulus Posticus and Dental Agenesis: A Retrospective Study
}

\author{
Alessandra Putrino ${ }^{1, *}$, Rosa Maria Leonardi ${ }^{2}$, Ersilia Barbato ${ }^{1}$ and Gabriella Galluccio ${ }^{1}$

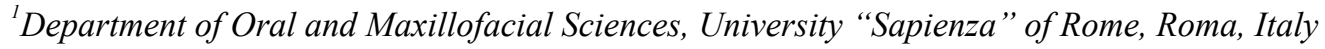 \\ ${ }^{2}$ Department of Medical and Surgical Sciences, II Dental Unity, University of Catania, Catania, Italy
}

Received: March 30, 2018

Revised: June 25, 2018

Accepted: July 16, 2018

\begin{abstract}
:
Objective:

Neural tube defects may increase the risk of an abnormal development of skull, vertebral column and teeth formation, including dental agenesis in non syndromic patients. The association between the presence of a congenital Dental Agenesis (DA) and the Atlantooccipital Ligament (AOL) calcification, known as "Ponticulus Posticus" (PP), as possible links can be investigated.
\end{abstract}

\section{Design:}

After a systematic review of the scientific literature on this topic, two independent examiners assessed the AOL calcification in lateral cephalograms of 350 non syndromic patients(7-21 years old). The results were compared with a control group (non syndromic patients, without congenital missing teeth).

\section{Results:}

The $16.3 \%$ of the population studied by cephalometric analysis revealed a prevalence rate of PP (both complete and partial) with a slight male predominance is seen, not statistically significant ( $\chi$ square test $=0.09 ; p=0.76$ ). In both sexes complete PP is more observed. In the patients affected by DA the frequency of PP is the $66.6 \%$ (both complete than partial). The $\chi$ square test with Yates correction showed a significative difference $(\chi=66.20 ; p$ value $=0.00)$ between PP in patients with DA compared to not affected by DA.

\section{Conclusions:}

PP is not an uncommon anomaly. Since orofacial pain like migraine and other symptoms are often associated to PP, during routine radiographic examination, if detected, it should be documented in patients' health record and with symptoms, further investigation should be sought for. These findings encourage to think there's an association between DA in non syndromic patients and neurocrestal cells defects.

Keywords: Dental anomalies, Ponticulus Posticus (PP), Dental Agenesis (DA), Atlantooccipital Ligament (AOL), Oligodontia, Hypodontia, Anodontia.

\section{INTRODUCTION}

Many of the common dental anomalies affecting the human dentition during odontogenesis are interrelated to the embryologic processes involved in facial, jaws and vertebral column development. The related molecular and genetic factors control these events are well documented in literature. The most common congenital dental anomaly is the absence of teeth, it can affect permanent and deciduous dentition.

\footnotetext{
"Address correspondence to the author at the Department of Oral and Maxillofacial Sciences, University "Sapienza" of Rome, Roma, Italy; Tel: +390672016195; E-mail: alessandra.putrino@gmail.com
} 


\subsection{Dental Agenesis}

Excluding third molars, when the absence of one to six teeth is observed it's defined "hypodontia", up to six teeth is "oligodontia", while the absence of all teeth is "anodontia" [1 - 3]. Hypodontia is usually associated with other oral and dental and altered craniofacial growth [4]. Dental agenesis can occur in non-syndromic population [5, 6], like familiar form, or be part of a multi-symptomatic syndrome [7]. In the majority of cases dental agenesis has genetic origins but also dental traumas, infections like rubella, chemo or radiotherapy, disturbances in local innervations, environmental situations, may influence and lead to the congenital absence of teeth $[2,7]$.

During the daily clinical evaluation, especially in young and child patients, it's important to know about the correlation between dental agenesis and genetic mutations [8]. A wide number of genes are involved in tooth morphogenesis [9 - 11]. The primitive epithelium covers the stomodeum and the neural crest cells regulate the process of tooth development [12 - 14].

\subsection{Neural Crest Cells}

In many parts of the skull and the mouth, teeth included, there are tracks of the neural crest cells migrated from the original neural tube $[15,16]$. Neural crest constitutes a pluripotential mesenchyme that is the source of diverse tissue types: neural, glial, skeletal, connective, pigment, and secretory. In the head region, neural crest forms a major port ion of the skull, maxilla, mandible, auditory ossicles, hyoid bone, larynx, dental tissues (dentin, cementum), the periodontal ligament, the alveolar bone and the vertebral column [17 - 20]. Publications on adult populations confirm the association between malocclusions, skeletal deviations in both the jaws, skull base and cervical spine anomalies that can be prenatally observed [21 - 23].

\subsection{Ponticulus Posticus}

One of the skeletal column anomaly related to neural crest cells activity during foetal development is the ossification/calcification of the posterior atlanto-occipital ligament, known as "ponticulus posticus"(latin expression for "little posterior bridge"), which describes an "anomalous malformed bony bridge between the posterior portion of the superior articular process and the posterolateral portion of the superior margin of the posterior arch of the first cervical vertebra (atlas)" [24]. In its presence, "there is occlusion of the vertebral artery and patients with ponticulus posticus often display symptoms of vertebrobasilar insufficiency such as headache, vertigo and diplopia” [25].

The prevalence of ponticulus posticus has been reported to be between $5.1 \%$ and $37.8 \%$ in the Western population and a female predominance has been reported in the literature [25]. The ponticulus posticus radiologic evidence has been documented and classified as related to different levels of ossification. Three types of ponticulus posticus can be detected on cephalograms and lateral radiographs [26, 27]:

- Full type: A complete bony ring.

- Incomplete type: An uncomplete bony ring.

- Calcified type: A linear or amorphous calcification.

A research documented the presence of a mildest calcification in the sampled population more similar to a small spicule [28]. This retrospective study aims to search a significative involvement of neural crest cells, under genetic control, in patients affected by non syndromic hypodontia and by alterations of skeletal structures (presence of ponticulus posticus) using radiographic examinations.

\section{MATERIALS AND METHODS}

Before to collect the clinical data about patients involved in the study, a systematic review of the scientific literature published on PubMed, Lilacs and Scopus data base has been done. The key words used were: "atlanto-occipital ligament", "ponticulus posticus", "neural crest cells", "orthodontic". No restrictions of time and languages have been fixed. The results have been filtered and valued following our eligibility criteria and then organized following the PRISMA method [29]. It's a custom to ask and obtain informed consent for the scientific aims at the time patients access to orthodontic treatment in our unit.

We followed these inclusion criteria: 
- Abstracts available;

- Radiographic evaluation on lateral cephalograms;

- Non-syndromic population;

- Related to the aim of the study (orthodontic patients, research of ponticulus posticus anomaly);

The study was performed in December 2014 at the Unit of Orthodontics at University "La Sapienza" in Rome. Lateral cephalograms and panoramic radiographs were collected from the archives and examined for ponticulus posticus and dental agenesis. Patients with history of cleft lip palate, facial/dental traumas and vertebral surgery for the treatment of cervical spine were excluded. The sampled population of patients was Caucasian and African. In case of poor visualization or overlapping of the interested structures cephalograms have been not considered in this study.

The sampled population counted a total of 350 subjects (160 males and 190 females) with a mean age of 13 (Table 1).

Table 1. Distribution of patients sampled for the study.

\begin{tabular}{|c|c|c|c|}
\hline Sex & Number of Patients & Age Range & Mean Age \\
\hline Males & 160 & $7-21$ years & 13.4 \\
\hline Females & 190 & $7-21$ years & 12.5 \\
\hline Total & 350 & $7-21$ years & 12.9 \\
\hline
\end{tabular}

We considered the initial lateral cephalograms and orthopantomographs detecting the data at the early stage of clinical-radiographic observation. In those patients with dental agenesis but no ponticulus posticus, we considered also cephalograms subsequent to the first, if requested for orthodontic reasons, to exclude or confirm the presence of ponticulus posticus. In patients with a partial or not clear presence of ponticulus posticus, we also considered eventual next cephalograms, if attached to the clinical documentation. The radiographs were viewed on a flat monitor (LCD,Samsung) in JPEG format. The cephalograms on traditional films have been scanned (Epson Scanner) and saved as .jpeg files to zoom in/adjust in contrast the image and allow a better evaluation of the occipital-atlas vertebra relations. The inspection of each radiograph to detect the presence of any type of ponticulus posticus has been performed by two independent operators (AP and GG). To eliminate possible errors, 50 cephalograms choosed randomly have been reexamined separately by the same operators in January $2015(\mathrm{~K}$ test=100). All collected data were recorded on virtual sheets in Microsoft Excel 2007. Functions for statistical analysis have been properly selected. The $\chi$ square test with Yates correction was used to measure the association between ponticulus posticus and gender.

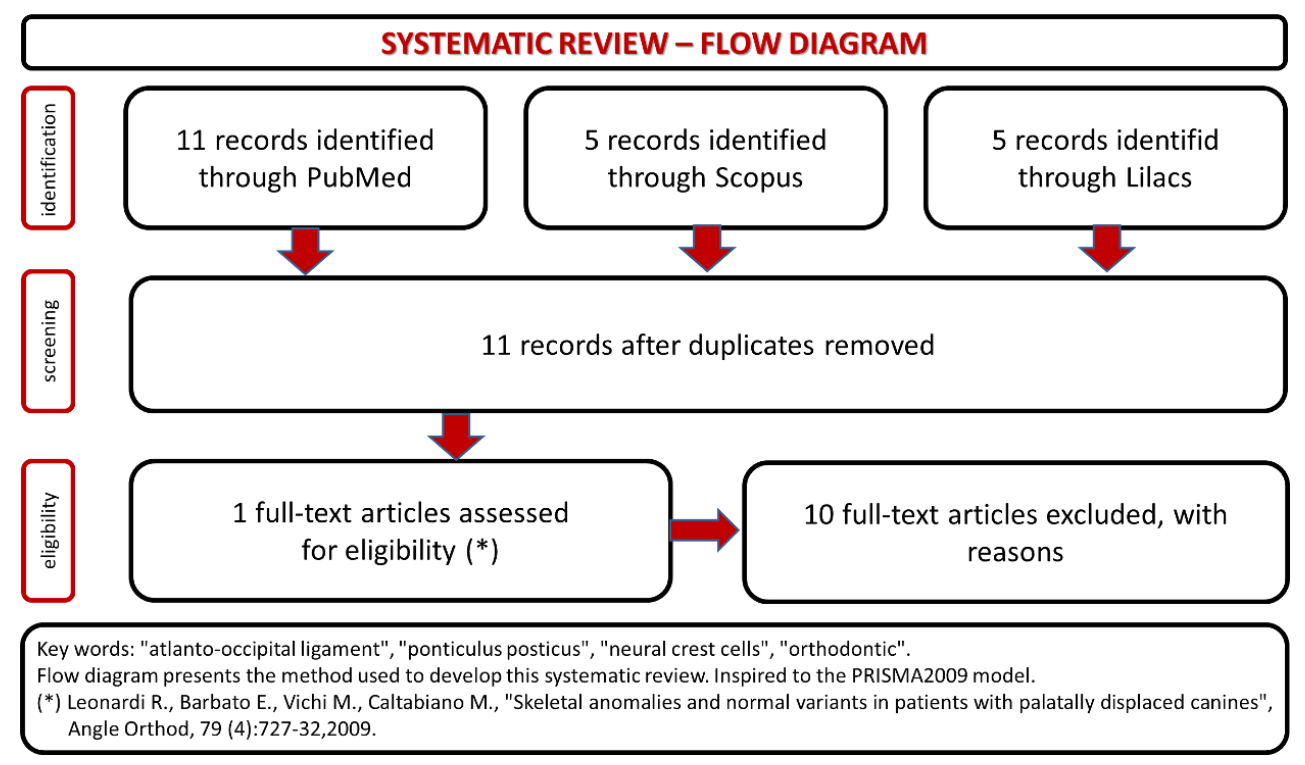

Fig. (1). Flow chart illustrates the pathway followed for a systematic review of literature about the aim of this study. 


\section{RESULTS}

The systematic review of the literature results have been summarized in the flow chart (Fig. 1). There's a poor production of articles related this topic, and even if all the papers considered in the study used cephalograms like diagnostic tool to find ponticulus posticus in patients, only one study searches a positive association between the presence of ponticulus posticus and dental/orthodontic evaluations [30]. The others are useful to document the incidence of ponticulus posticus in the population.

The direct inspection of the 350 lateral cephalograms (Fig. 2) has lead to find a prevalence rate of 32,95\% for both the types complete and partial ponticulus (Table 2), the presence of calcified type has never been observed. A slight male predominance without statistical relevance has been observed ( $\chi$ square test $=0.09 ; p$ value $=0.76)($ Table 3).

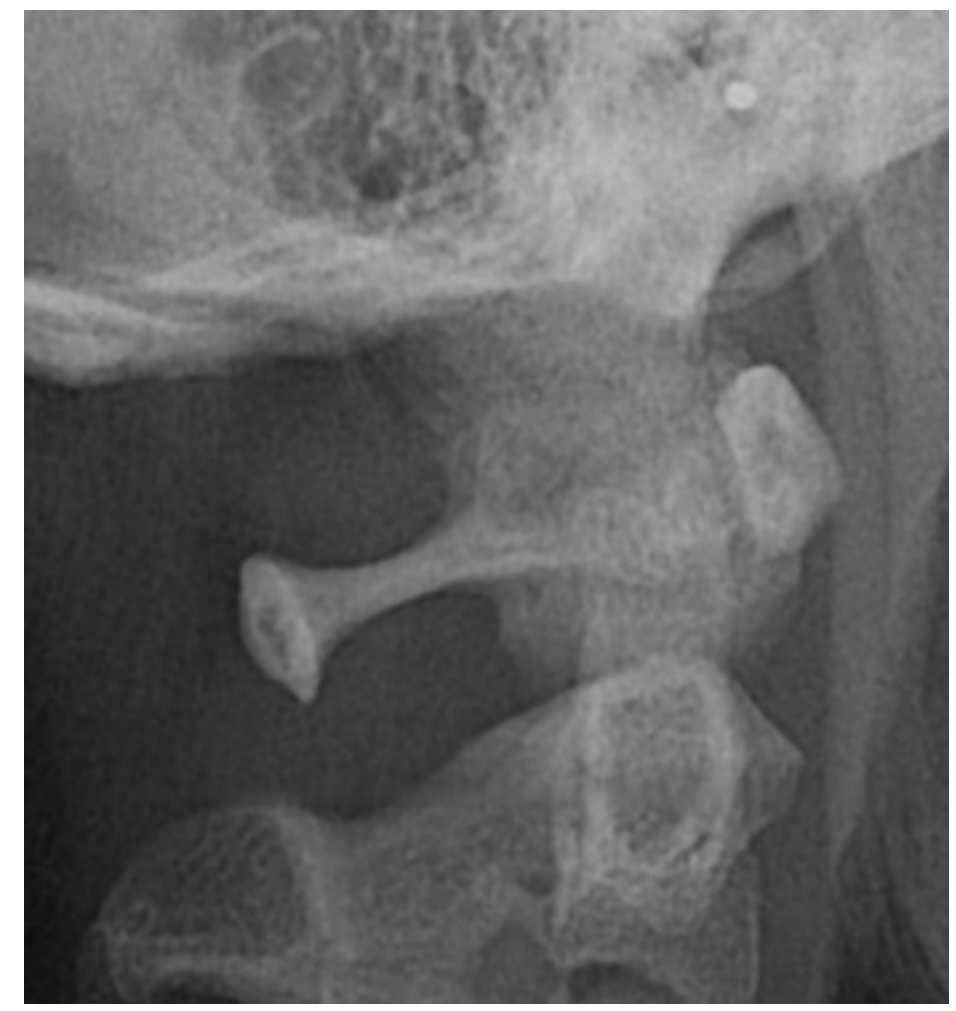

Fig. (2). Detail of a normal atlas as viewed on lateral cephalogram.

Table 2. Prevalence of two types of ponticulus posticus (linear never detected) in males and females patients selected in this study.s

\begin{tabular}{|c|c|c|}
\hline Type & Males & Females \\
\hline Complete & $20(12.5 \%)$ & $16(8.42 \%)$ \\
\hline Partial & $10(6.25 \%)$ & $11(5.78 \%)$ \\
\hline Calcified/Linear & $0(0 \%)$ & $0(0 \%)$ \\
\hline Total & $30(18.75 \%)$ & $27(14.2 \%)$ \\
\hline
\end{tabular}

Table 3. $\chi$ square test results even with Yates correction show no differences statistically significant about the distribution of ponticulus posticus in the gender male and female.

\begin{tabular}{|c|c|c|c|c|c|c|c|c|}
\hline \multicolumn{5}{|c|}{ Chi- Square Test } & 0,34 & \multicolumn{3}{|c|}{ Non significative difference } \\
\hline - & - & - & - & $p:$ & 0,5627 & - & - & - \\
\hline \multicolumn{5}{|c|}{ Chi-Square Test (with Yates correction): } & 0,09 & \multicolumn{3}{|c|}{ Non significative difference } \\
\hline - & - & - & - & $p:$ & 0,7612 & - & - & - \\
\hline
\end{tabular}


No disagreement intra-observer and between the two observers at the first and the second random examination has been found.

The prevalence rate of dental agenesis in the studied population is around $12 \%$. In order of frequency the tooth more often missing for agenesis is the upper lateral incisor, followed by second and first premolars, more often mandibular than maxillar. In the female like in the male patients is more observed complete ponticulus posticus than partial. In the patients affected by dental agenesis the frequency of ponticulus posticus (Fig. 3 and 4) is the 66.6\% (both complete than partial), it's not observable in the $33.3 \%$ of them. A percentage around $11 \%$ represents patients non affected by dental agenesis but with the evidence of a ponticulus posticus in their cephalograms. Three of them had the inclusion of canines, one had an history of relatives with non syndromic agenesis. Four cephalograms have been excluded for a not quality of the radiographic image. The measurement of prevalence of ponticulus posticus in patients with dental agenesis compared to the number of observations in patients not affected by dental agenesis has been calculated statistically by the $\chi$ square test with Yates correction (Table 4). The results show a significative difference $(\chi=66.20$; $p$-value $=0.00)($ Table 5). Anamnestic data available in the clinical diary attached to the radiographs of patients with ponticulus posticus in the archive don't describe migraines, column pains or whatever symptom related to the cervical ponticulus posticus, except one with dental agenesis too. The $70 \%$ of patients with ponticulus posticus not affected by dental agenesis showed to be a II class (skeletal).

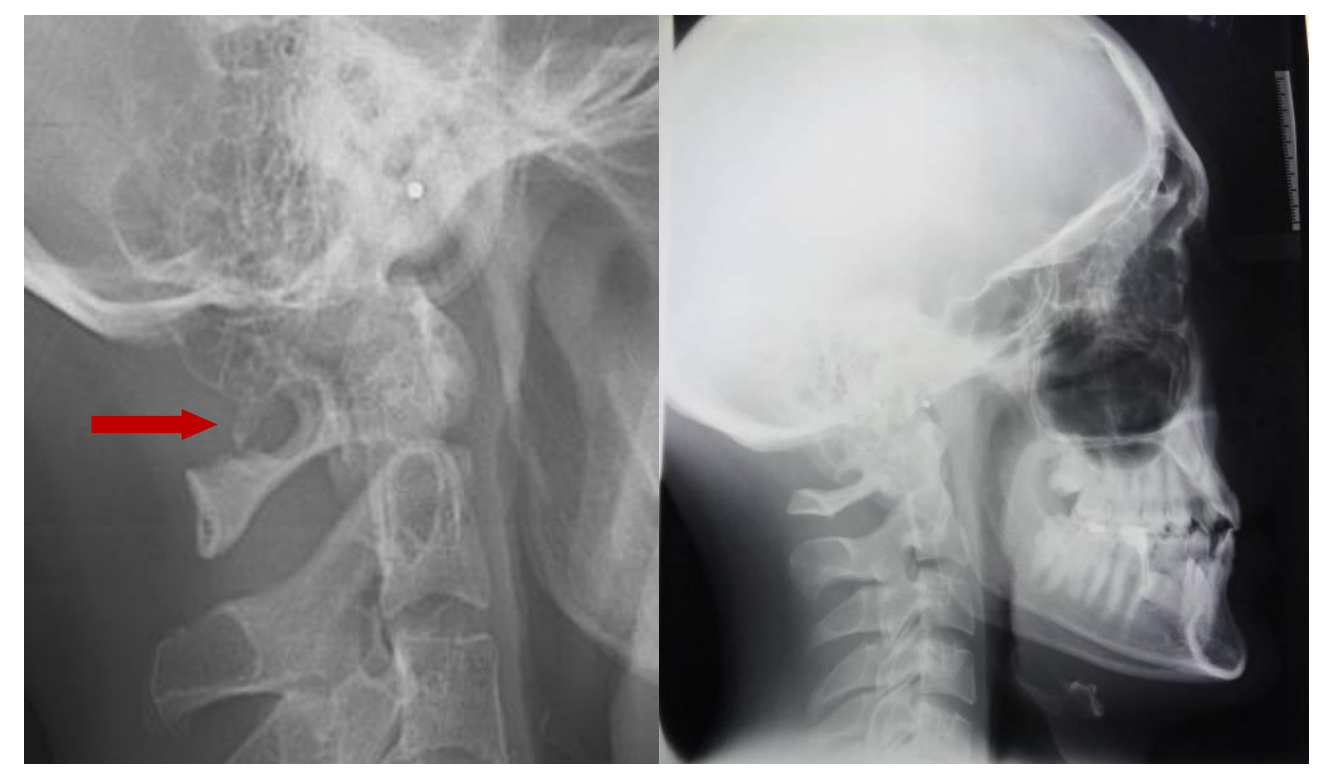

Fig. (3). Detail of cephalogram showing partial type ponticulus posticus on the left, and cephalogram showing a partial ponticulus posticus in a patient with agenesis of 35 .

Table 4. Distribution of radiographic evidence of ponticulus posticus in patients with and without dental agenesis.

\begin{tabular}{|c|c|c|c|}
\hline Radiographic Evidence & Patients with Dental Agenesis & Patient without Dental Agenesis & Total \\
\hline Ponticulus Posticus & $28(8 \%)$ & $39(11 \%)$ & $67(19 \%)$ \\
\hline No Ponticulus Posticus & $14(4 \%)$ & $269(77 \%)$ & $283(81 \%)$ \\
\hline Total & $42(12 \%)$ & $308(88 \%)$ & $350(100 \%)$ \\
\hline
\end{tabular}

Table 5. $\chi$ square test results even with Yates correction show differences statistically significant about the distribution of ponticulus posticus in the patients with and without dental agenesis.

\begin{tabular}{|c|c|c|c|c|c|c|c|c|c|}
\hline \multicolumn{5}{|c|}{ Chi-Square Test } & 69,64 & \multicolumn{4}{|c|}{ Significative difference (prob. 1\%) } \\
\hline- & - & - & - & $p:$ & 0,0000 & - & - & - & - \\
\hline \multicolumn{5}{|c|}{ Chi - Square Test (with Yates correction): } & 66,20 & \multicolumn{4}{|c|}{ Significative difference (prob. 1\%) } \\
\hline- & - & - & - & $p:$ & 0,0000 & - & - & - & - \\
\hline
\end{tabular}




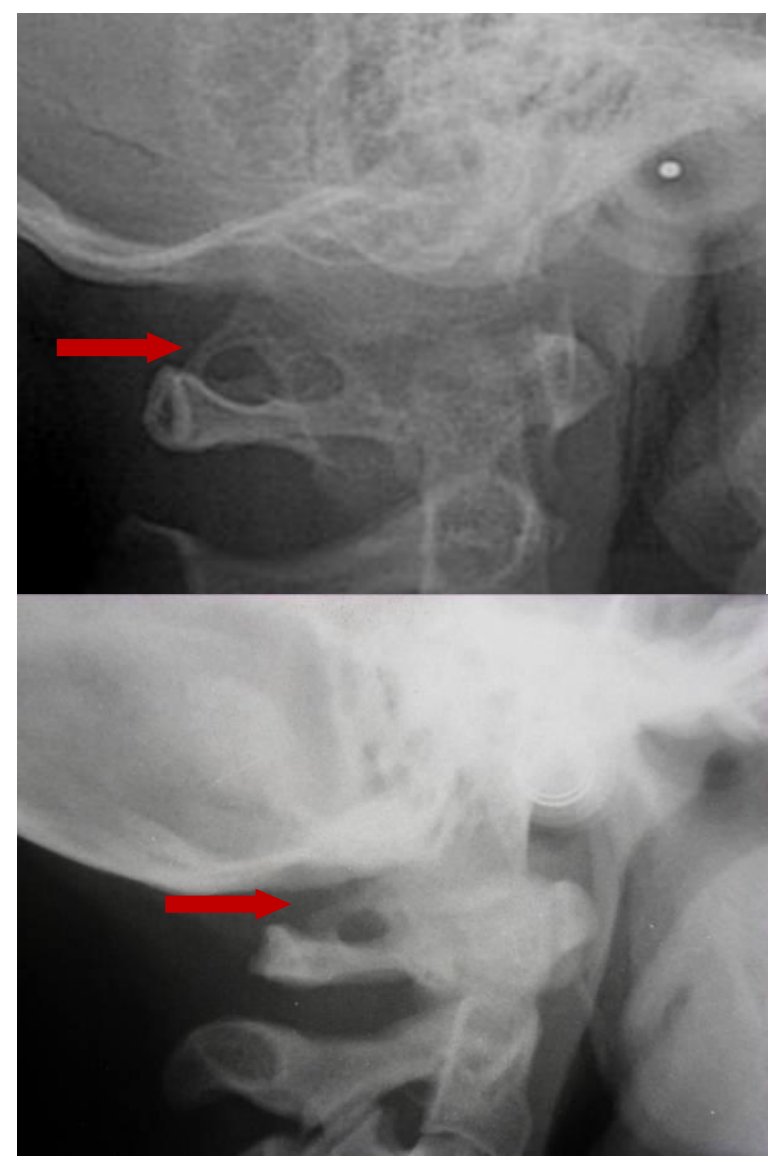

Fig. (4). Detail of cephalogram showing a complete ponticulus posticus and a full cephalogram of patient with agenesis of 45 and complete ponticulus posticus.

\section{DISCUSSION}

Different studies esteemed the rate of prevalence ponticulus posticus around $5.1 \%$ and $37.8 \%[31,32]$. The prevalence of the complete type has been reported to be $2.6 \%$ and $14.3 \%$ like radiographic finding and around $3.4 \%$ and $15 \%$ in osteological researches [33]. A study on cephalograms of Peruvian patients [34] documented a frequency of complete ponticulus posticus in $19.79 \%$, partial on $11.08 \%$. In the article documents our research the complete type of ponticulus posticus has been found in $19 \%$ of the patients. A female prevalence has been reported in literature $[32,35,36,24]$, but our study results show a different trend, even if it's proved to be not statistically significant. Indian orthodontic patients [25] showed a prevalence of complete ponticulus posticus $(4.3 \%)$ lower the rate found in this study (20.92\%). The same study compared to our results showed opposite trends for gender prevalence: male (5.33\%) for them, over female (3.76\%) for us. In the study done by Gupta et al, complete ponticulus posticus, recorded in $11.1 \%$ of sampled patients, is seen in $2.8 \%$ of males and $3.1 \%$ of females [24]. In our study we found a significative evidence of ponticulus posticus in patients with dental agenesis without predominance of partial or complete posticus related to age or gender of these patients. In a study Leonardi R. et al. (2009) found a positive association of ponticulus posticus in patients with impacted canines [30]. The age doesn't seem to influence the level of ossification of atlanto-occipital ligament, since we observed complete ponticulus posticus in very young children (7-8 years old) and at the same time partial ponticulus posticus in older children, adolescents and young adults too. We can't admit ponticulus posticus evolve necessarily from an initial to a complete type.

The prevalence of ponticulus posticus is strictly influenced by the quality, diagnostic power and level of radiographic images like documented in a study performed on Korean population [36] where, on the same population studied, the prevalence of this anomaly increased from $6.95 \%$ using a plain radiograph to $15.5 \%$ using a 3D CT scan. Also in another study [37] the prevalence documented was higher than in our results, around $45.9 \%$, but this difference can be attributed to the numbers of the patients sampled, double than ours. There are no reports on whether the ponticulus posticus represents the result of bone formation by heterotopic ossification or a mineralized sof tissue by 
ectopic calcification [38]. Tubbs et al. (2007), noted that the no ossification centers can be found in ligaments involved in ponticulus posticus structure [39]. Crowe (1986) found ponticulus posticus in patients younger than 15 years old and those findings suggest that the ponticulus posticus is not a calcified ligament and not related to ligamental stress , because ligamentous calcification occurs years following the final formation of bone, and then following prolonged stress [40]. Hong et al. (2008) found statistically significant differences between the partial and complete ponticulus posticus, and suggested that the formation of a ponticulus posticus would appear to be similar to osteophyte formation, a condition also related to age [41]. The population for the present study was predominantly under 18 years because of being an orthodontic population and the differences found for the age variable are in agreement with the findings reported by Tubbs et al., Crowe and Hong et al [39 - 41]. In the study documented by Paraskevas et al. (2005) a progressive calcification has been reported [42]. The importance of early identification of this anomaly on routine lateral cephalograms asked for orthodontic diagnosis is enhanced by the correlation with its presence and the diagnosis of popular disturbs like migraine [43], detected in the $15.8 \%$ of cases sampled with ponticulus posticus, the association with TMJ disorders [44, 45], or in the identification of more rare clinical pictures like in the nevoid cell carcinoma syndrome [46]. Especially in all of those cases of orofacial pain disorders, migraines and chronic tension type headaches, the patient giving evidence is essential bearing in mind that complications related to this vertebral anomaly can lead to the need of cervical spine surgery $[47,48,35]$. The history of symptoms is absent in our study, since it has been designed like a retrospective research and data collected by patients' clinical diaries are lack of these informations able to further prove those linkings documented in literature and cited above but we can't exclude our patients are asymptomatic.

\section{CONCLUSION}

This study showed that ponticulus posticus is not an uncommon or definetely rare anomaly in the Italian population, and its positive relation with dental anomalies, like dental agenesis, encourage us to believe in the power and importance of basic investigation on cephalograms. When detected, in our routine radiographic examination, it should be documented in patients' health records, especially in the symptomatic ones. The relationship between the prenatal development of the cranium and some related structures like teeth and column are under the control of same genes and this process, with the possible abnormal activities and results, can't be considered a field of interest confined to genetics. Our study indeed showed how this relationship can influence our orthodontic diagnosis making our treatment planning more complete and our daily activity more precious and helpful in the management of our patients' health beyond our field of intervention and practice just being able to read the not so hidden findings of our regular investigation tools.

\section{CONTRIBUTORS}

All Authors above mentioned have materially participated in the research and article preparation.

All Authors have read and approved the final article.

\section{AUTHORSHIP}

1) Alessandra Putrino: The conception and design of the study, acquisition of data, drafting the article

2) Rosa Maria Leonardi: Analysis and interpretation of data

3) Ersilia Barbato: Analysis and interpretation of data; critical revision of article.

4) Gabriella Galluccio: Acquisition of data; drafting the article and final approval of the version to be submitted

\section{ETHICS APPROVAL AND CONSENT TO PARTICIPATE}

This study received the ethical approval $n^{\circ} 3802$ on 24/09/2015 released from the Ethical Committee of the Azienda Policlinico Umberto I- Sapienza University of Rome.

\section{HUMAN AND ANIMAL RIGHTS}

No animals were used in this research. All research procedures followed were in accordance with the ethical standards of the committee responsible for human experimentation (institutional and national), and with the Helsinki Declaration of 1975 , as revised in 2008. 


\section{CONSENT FOR PUBLICATION}

All participants accepted to offer for the approved by Ethical Commitee wide-ranging epidemiological study their data with a written and informed consent.

\section{CONFLICT OF INTERESTS}

The authors declare no conflict of interest, financial or otherwise.

\section{ACKNOWLEDGEMENTS}

Declared none.

\section{REFERENCES}

[1] Burzynski NJ, Escobar VH. Classification and genetics of numeric anomalies of dentition. Birth Defects Orig Artic Ser 1983; 19(1): 95-106. [PMID: 6362744]

[2] Miletich I, Sharpe PT. Normal and abnormal dental development. Hum Mol Genet 2003; 12 (Spec No 1): R69-73. [http://dx.doi.org/10.1093/hmg/ddg085] [PMID: 12668599]

[3] Cai J, Cho S-W, Kim J-Y, Lee M-J, Cha Y-G, Jung H-S. Patterning the size and number of tooth and its cusps. Dev Biol 2007; 304(2): 499-507.

[http://dx.doi.org/10.1016/j.ydbio.2007.01.002] [PMID: 17289014]

[4] Moore KL, Persaud TVN, Torchia MG, Eds. Eds. The developing human: Clinically oriented embryology. $9^{\text {th }}$ ed. Elsevier 2008 ; pp. 560

[5] Han D, Gong Y, Wu H, et al. Novel EDA mutation resulting in X-linked non-syndromic hypodontia and the pattern of EDA-associated isolated tooth agenesis. Eur J Med Genet 2008; 51(6): 536-46.

[http://dx.doi.org/10.1016/j.ejmg.2008.06.002] [PMID: 18657636]

[6] Galluccio G, Castellano M, La Monaca C. Genetic basis of non-syndromic anomalies of human tooth number. Arch Oral Biol 2012; 57(7): 918-30.

[http://dx.doi.org/10.1016/j.archoralbio.2012.01.005] [PMID: 22325622]

[7] Hand AR, Frank ME. Fundamentals of oral histology and physiology. Wiley Blackewell 2014; pp. 296

[8] Galluccio G, Pilotto A. Genetics of dental agenesis: Anterior and posterior area of the arch. Eur Arch Paediatr Dent 2008; 9(1): 41-5. [http://dx.doi.org/10.1007/BF03321595] [PMID: 18328238]

[9] Alappat S, Zhang ZY, Chen YP. Msx homeobox gene family and craniofacial development. Cell Res 2003; 13(6): 429-42. [http://dx.doi.org/10.1038/sj.cr.7290185] [PMID: 14728799]

[10] Alvesalo L. Human sex chromosomes in oral and craniofacial growth. Arch Oral Biol 2009; 54(Suppl. 1): S18-24. [http://dx.doi.org/10.1016/j.archoralbio.2008.06.004] [PMID: 18657798]

[11] Andl T, Reddy ST, Gaddapara T, Millar SE. WNT signals are required for the initiation of hair follicle development. Dev Cell 2002; 2(5): 643-53. [http://dx.doi.org/10.1016/S1534-5807(02)00167-3] [PMID: 12015971]

[12] Bouwman P, Göllner H, Elsässer HP, et al. Transcription factor Sp3 is essential for post-natal survival and late tooth development. EMBO J 2000; 19(4): 655-61.

[http://dx.doi.org/10.1093/emboj/19.4.655] [PMID: 10675334]

[13] Townsend GC, Richards L, Hughes T, Pinkerton S, Schwerdt W. Epigenetic influences may explain dental differences in monozygotic twin pairs. Aust Dent J 2005; 50(2): 95-100.

[http://dx.doi.org/10.1111/j.1834-7819.2005.tb00347.x] [PMID: 16050088]

[14] Brook AH. Multilevel complex interactions between genetic, epigenetic and environmental factors in the aetiology of anomalies of dental development. Arch Oral Biol 2009; 54(Suppl. 1): S3-S17. [http://dx.doi.org/10.1016/j.archoralbio.2009.09.005] [PMID: 19913215]

[15] Gritli-Linde A, Bei M, Maas R, Zhang XM, Linde A, McMahon AP. Shh signaling within the dental epithelium is necessary for cell proliferation, growth and polarization. Development 2002; 129(23): 5323-37. [http://dx.doi.org/10.1242/dev.00100] [PMID: 12403705]

[16] Rothová M, Peterková R, Tucker AS. Fate map of the dental mesenchyme: Dynamic development of the dental papilla and follicle. Dev Biol 2012; 366(2): 244-54.

[http://dx.doi.org/10.1016/j.ydbio.2012.03.018] [PMID: 22542602]

[17] Dassule HR, McMahon AP. Analysis of epithelial-mesenchymal interactions in the initial morphogenesis of the mammalian tooth. Dev Biol 1998; 202(2): 215-27. [http://dx.doi.org/10.1006/dbio.1998.8992] [PMID: 9769173]

[18] Kjaer I. Orthodontics and foetal pathology: A personal view on craniofacial patterning. Eur J Orthod 2010; $32(2)$ : 140-7. [http://dx.doi.org/10.1093/ejo/cjp059] [PMID: 19635743] 
[19] Kjær I. Orthodontics and foetal pathology: A personal view on craniofacial patterning. Eur J Orthod 2010; 32 : $40-7$. [PMID: 19635743]

[20] Ishida K, Murofushi M, Nakao K, Morita R, Ogawa M, Tsuji T. The regulation of tooth morphogenesis is associated with epithelial cell proliferation and the expression of Sonic hedgehog through epithelial-mesenchymal interactions. Biochem Biophys Res Commun 2011; 405(3): 455-61.

[http://dx.doi.org/10.1016/j.bbrc.2011.01.052] [PMID: 21255557]

[21] Sonnesen L, Pedersen CE, Kjaer I. Cervical column morphology related to head posture, cranial base angle, and condylar malformation. Eur J Orthod 2007; 29(4): 398-403.

[http://dx.doi.org/10.1093/ejo/cjm010] [PMID: 17607022]

[22] Sonnesen L, Kjaer I. Cervical column morphology in patients with skeletal open bite. Orthod Craniofac Res 2008; 11(1): 17-23. a [http://dx.doi.org/10.1111/j.1601-6343.2008.00409.x] [PMID: 18199076]

[23] Sonnesen L, Kjaer I. Anomalies of the cervical vertebrae in patients with skeletal Class II malocclusion and horizontal maxillary overjet. Am J Orthod Dentofacial Orthop 2008; 133(2): 188.e15-20. b [http://dx.doi.org/10.1016/j.ajodo.2007.07.018] [PMID: 18249281]

[24] Mudit G, Srinivas K, Satheesha R. Retrospective analysis of ponticulus posticus in Indian orthodontic patients-a lateral cephalometric study. Ethiop J Health Sci 2014; 24(4): 285-90. [http://dx.doi.org/10.4314/ejhs.v24i4.2] [PMID: 25489191]

[25] Sharma V, Chaudhary D, Mitra R. Prevalence of ponticulus posticus in Indian orthodontic patients. Dentomaxillofac Radiol 2010; 39(5): 277-83.

[http://dx.doi.org/10.1259/dmfr/16271087] [PMID: 20587651]

[26] Miki T, Oka M, Urushidani H, Hirofuji E, Tanaka S. Iwamoto. Ponticulus posticus: Its clinical significance. Acta Med Kinki Univ 1979; 4(2): 427-30.

[27] Chitroda PK, Katti G, Baba IA, et al. Ponticulus posticus on the posterior arch of atlas, prevalence analysis in symptomatic and asymptomatic patients of gulbarga population. J Clin Diagn Res 2013; 7(12): 3044-7.

[PMID: 24551723]

[28] Kim KH, Park KW, Manh TH, Yeom JS, Chang BS, Lee CK. Prevalence and morphologic features of ponticulus posticus in Koreans: Analysis of 312 radiographs and 225 three-dimensional CT scans. Asian Spine J 2007; 1(1): $27-31$. [http://dx.doi.org/10.4184/asj.2007.1.1.27] [PMID: 20411149]

[29] Moher D, Liberati A, Tetzlaff J, Altman DG. Preferred reporting items for systematic reviews and meta-analyses: The PRISMA statement. PLoS Med 2009; 6(7): e1000097.

[http://dx.doi.org/10.1371/journal.pmed.1000097] [PMID: 19621072]

[30] Leonardi R, Barbato E, Vichi M, Caltabiano M. Skeletal anomalies and normal variants in patients with palatally displaced canines. Angle Orthod 2009; 79(4): 727-32. [http://dx.doi.org/10.2319/082408-448.1] [PMID: 19537879]

[31] Young JP, Young PH, Ackermann MJ, Anderson PA, Riew KD. The ponticulus posticus: Implications for screw insertion into the first cervical lateral mass. J Bone Joint Surg Am 2005; 87(11): 2495-8. [PMID: 16264126]

[32] Stubbs DM. The arcuate foramen. Variability in distribution related to race and sex. Spine 1992; 17(12): 1502-4 [http://dx.doi.org/10.1097/00007632-199212000-00010] [PMID: 1471009]

[33] Unur E, Erdogan N, Ulger H, Ekinci N, Ozturk O. U* lger H, Ekinci N, Radiographic incidence of complete arcuate foramen in Turkish population. Erciyes Med J 2004; 26(2): 50-4.

[34] Pérez IE, Chavez AK, Ponce D. Frequency of ponticulus posticus in lateral cephalometric radiography of peruvian patients. Int J Morphol 2014; 32(1): 54-60. [http://dx.doi.org/10.4067/S0717-95022014000100010]

[35] Schilling J, Schilling A, Suazo GI. Ponticulus posticus on the posterior arch of atlas, prevalence analysis in asymptomatic patients. Int J Morphol 2010; 28(1): 317-22.

[http://dx.doi.org/10.4067/S0717-95022010000100046]

[36] Cho YJ. Radiological analysis of ponticulus posticus in Koreans. Yonsei Med J 2009; 50(1): 45-9. [http://dx.doi.org/10.3349/ymj.2009.50.1.45] [PMID: 19259347]

[37] Kuhta P, Hart J, Greene-Orndorff L, McDowell-Reizer B, Rush P. The prevalence of posticus ponticus: Retrospective analysis of radiographs from a chiropractic health center. J Chiropr Med 2010; 9(4): 162-5. [http://dx.doi.org/10.1016/j.jcm.2010.07.004] [PMID: 22027107]

[38] Vanden Bossche L, Vanderstraeten G. Heterotopic ossification: A review. J Rehabil Med 2005; 37(3): $129-36$. [http://dx.doi.org/10.1080/16501970510027628] [PMID: 16040468]

[39] Tubbs RS, Johnson PC, Shoja MM, Loukas M, Oakes WJ. Foramen arcuale: Anatomical study and review of the literature. J Neurosurg Spine 2007; 6(1): 31-4.

[http://dx.doi.org/10.3171/spi.2007.6.1.6] [PMID: 17233288] 
[40] Crowe SH. The ponticulus posticus of the atlas vertebra and its significance. Upper Cerv Monogr 1986; 4(1): 1-5.

[41] Hong JT, Lee SW, Son BC, et al. Analysis of anatomical variations of bone and vascular structures around the posterior atlantal arch using three-dimensional computed tomography angiography. J Neurosurg Spine 2008; 8(3): 230-6. [http://dx.doi.org/10.3171/SPI/2008/8/3/230] [PMID: 18312074]

[42] Paraskevas G, Papaziogas B, Tsonidis C, Kapetanos G. Gross morphology of the bridges over the vertebral artery groove on the atlas. Surg Radiol Anat 2005; 27(2): 129-36.

[http://dx.doi.org/10.1007/s00276-004-0300-9] [PMID: 15800734]

[43] Kendrick GS, Biggs NL. Incidence of the ponticulus posticus of the first cervical vertebra between ages six to seventeen. Anat Rec 1963; 145: 449-53.

[http://dx.doi.org/10.1002/ar.1091450308] [PMID: 14031912]

[44] Gonçalves DA, Camparis CM, Speciali JG, Franco AL, Castanharo SM, Bigal ME. Temporomandibular disorders are differentially associated with headache diagnoses: A controlled study. Clin J Pain 2011; 27(7): 611-5. [http://dx.doi.org/10.1097/AJP.0b013e31820e12f5] [PMID: 21368664]

[45] Plesh O, Adams SH, Gansky SA. Self-reported comorbid pains in severe headaches or migraines in a US national sample. Headache 2012; 52(6): 946-56.

[http://dx.doi.org/10.1111/j.1526-4610.2012.02155.x] [PMID: 22553936]

[46] Leonardi R, Santarelli A, Barbato E, et al. Atlanto-occipital ligament calcification: A novel sign in nevoid basal cell carcinoma syndrome. Anticancer Res 2010; 30(10): 4265-7. [PMID: 21036751]

[47] Wight S, Osborne N, Breen AC. Incidence of ponticulus posterior of the atlas in migraine and cervicogenic headache. J Manipulative Physiol Ther 1999; 22(1): 15-20. [http://dx.doi.org/10.1016/S0161-4754(99)70100-4] [PMID: 10029944]

[48] Cakmak O, Gurdal E, Ekinci G, Yildiz E, Cavdar S. Arcuate foramen and its clinical significance. Saudi Med J 2005; 26(9): 1409-13. [PMID: 16155658]

(C) 2018 Putrino et al.

This is an open access article distributed under the terms of the Creative Commons Attribution 4.0 International Public License (CC-BY 4.0), a copy of which is available at: (https://creativecommons.org/licenses/by/4.0/legalcode). This license permits unrestricted use, distribution, and reproduction in any medium, provided the original author and source are credited. 